Polymer Journal, Vol. 39, No. 6, pp. 551-557 (2007)

(C) 2007 The Society of Polymer Science, Japan

\title{
Synthesis and Characterization of Hyperbranched Poly(siloxysilane) Possessing Rhodamine B as Terminal Group
}

\author{
Lujun Ding, Teruaki HaYAKAwA, and Masa-aki KAKIMOTO ${ }^{\dagger}$ \\ Department of Organic \& Polymeric Materials, Tokyo Institute of Technology, \\ 2-12-1 O-okayama, Meguro-ku, Tokyo 152-8552, Japan
}

(Received October 31, 2006; Accepted March 8, 2007; Published April 23, 2007)

\begin{abstract}
The hyperbranched poly(siloxysilane) possessing rhodamine B (HBPS-RB) group on the terminal position was synthesized by esterification of hyperbranched poly(siloxysilane) with hydroxyl terminal group and RB in the presence of DCC and DMAP. Two derivative hyperbranched poly(siloxysilane)s containing vinyl(HBPS-V) and hydroxyl (HBPS-OH) terminal groups were prepared by hydrosilylation of bis(dimethylvinylsilyl) methylsiloxane $\left(\mathrm{AB}_{2}\right)$ and radical addition of 2-mercaptoethanol using AIBN as initiator, respectively. The structures of the polymers were characterized by the ${ }^{1} \mathrm{H}$ NMR, ${ }^{13} \mathrm{C}$ NMR and Fourier Transform Infrared (FT-IR) spectra. The molecular weights were measured by gel permeation chromatography (GPC). The UV-Visible absorption spectra indicate that $34 \% \mathrm{RB}$ was conjugated to polymer. Fluorescence spectrum indicated that aggregation of RB was depressed in the polymer because RB molecules were separated by branch of polymer molecules.

[doi:10.1295/polymj.PJ2006144]

KEY WORDS Hyperbranched Polymer / Poly(siloxysilane) / Rhodamine B / Conjugation / Aggregation /
\end{abstract}

Rhodamine B (RB), which has a high absorption coefficient and fluorescent yield, is attracting increasing attention with respect to novel applications, such as characterizing laser systems, examining the efficiency of various pump sources and obtaining highpower lasers. ${ }^{1,2}$ The dye is commonly used in alcoholic solution and aqueous dye solution. Unfortunately, $\mathrm{RB}$ aggregates in these solutions at high concentration leading to quench internally the dye fluorescence and prevent effective lasing. ${ }^{3-5}$ This problem has been dealt with in the past by adding detergents or using matrix. Many matrix such as linear polymer, colloids, high surface area porous glasses, and dendrimers etc, have been used to carry RB as well as other dyes. ${ }^{6-12}$ Linear polymers as dye matrix have been studied for many years. However, the amount of dye embedded or conjugated to linear polymer is limited because of limited end group. Recently, dendritic polymers have become very interesting in laser application due to their regular structures. ${ }^{13-15}$ However, most dendrimers containing limited functional groups are established through difficult preparative steps and sometimes identified with inadequate analytical methods. ${ }^{16}$

Comparison with dendrimers, hyperbranched polymers prepared in one-step synthesis, which can reduce costs and environment pollution, are very attractive for both laboratory and commercial preparations. ${ }^{17-22}$ Furthermore, hyperbranched polymers, which possess a highly branched backbone and a large number of ter- minal groups, show many interesting properties similar to dendrimers, such as low viscosity, high solubility due to less chain entanglement, and feasibility to be further modified through various chemical reaction of the peripheral groups because of the branching structural characteristics. ${ }^{23-27}$ The high fluorescence quantum yield will be obtained if RB is conjugated to these kinds of polymers. Comparison with carbon-based polymers, siloxane-based polymers, and particularly poly(siloxane)s, possess excellent properties such as inorganic-organic interaction that lead to a wide range of applications in coatings, adhesives, cosmetics and surfactants. ${ }^{28-32}$ The study of hyperbranched siloxane-type polymers have become an especial appealing area. ${ }^{33-35}$ Some hyperbranched poly(siloxysilane)s have been reported via hydrosilylation reaction. ${ }^{36-39}$ Finally, RB conjugated HBPS was easily absorbed to silica beads using as laser emission materials.

In this work, hyperbrabched poly(siloxysilane) was selected as RB matrix because they have characters of hyperbranched polymers and strong inorganic-organic interaction with silica beads. Furthermore, hyperbranched poly(siloxysilane), which has three dimension structure, can prevent conjugated RB from aggregation in solutions.

In this paper, the synthesis and characterization of hyperbranched poly(siloxysilane)s end-capped with RB group are mainly described.

${ }^{\dagger}$ To whom correspondence should be addressed (Tel: +81-3-5734-2433, Fax: +81-3-5734-2875, E-mail: mkakimot@o.cc.titech.ac.jp). 


\section{EXPERIMENTAL}

\section{Measurement}

${ }^{1} \mathrm{H}$ NMR and ${ }^{13} \mathrm{C}$ NMR measurements were carried out by a JEOL JNM-AL $300 \mathrm{MHz}$ spectrometer in $\mathrm{CDCl}_{3}, \mathrm{DMSO}-d_{6}$ or $\mathrm{CD}_{3} \mathrm{OD}$ without TMS. Infrared spectra were obtained using a JASCO FT-IR 460 Plus Fourier-transform infrared spectrophotometer. Gel permeation chromatography (GPC) measurements were performed with JASCO HPLC 880PU, and a Shodx KF-802.5 column (using THF as the eluent). Thermo gravimetric analysis (TGA) and differential scanning calorimetry (DSC) were carried out with a Seiko TGA 6200 and a Seiko DSC 6200 with a heating rate of $10{ }^{\circ} \mathrm{C} \mathrm{min}^{-1}$ under $\mathrm{N}_{2}$. UV-visible spectra were performed with UV-2800. Fluorescence spectra were obtained using JASCO Corp., FP-750.

\section{Materials}

Bis(dimethylvinylsilyl) methylsiloxane as an $\mathrm{AB}_{2}$ type monomer was purchased from Kozima Chemical Inc. Japan and purified by distillation before use. The chemicals $N, N^{\prime}$-dicyclohexylcarbodi-imide (DCC, Tokyo Kasei, 98\%) 4-dimethylamino-pyridine (DMAP, Tokyo Kasei, 98\%), Rhodamine B (Aldrich, dye content 90\%), platinum(0)-1,3-divinyl-1,1,3,3tetramethyldisiloxane complex $3 \%$ solution in xylene (Pt), 2-hydroxyethylthio (Aldrich, 98\%), 2,2'-azobis(2-isobutyronitrile) (AIBN, Tokyo Kasei, 98\%) were used as received without purification.

Synthesis of Hyperbranched Poly(siloxysilane) with Vinyl Terminal Group (HBPS-V)

A $50 \mathrm{~mL}$ round-bottom flask equipped with a magnetic stirrer, and gas-inlet was charged with catalyst $\mathrm{Pt}$ $0.001 \mathrm{~g}(2.65 \mathrm{mmol})$, and $\mathrm{AB}_{2}$ monomer bis(dimethylvinylsilyl) methylsiloxane $13.13 \mathrm{~g}(53.0 \mathrm{mmol})$. The reaction was kept $5 \mathrm{~min}$ in ice-bath with stirring under argon condition. This reaction was continuing for $3 \mathrm{~h}$ at room temperature until no $\mathrm{H}-\mathrm{Si}$ proton was detected by IR or NMR spectroscopy. The polymer was dissolved in diethyl ether $(30 \mathrm{~mL})$ and precipitated in methanol $500 \mathrm{~mL}$ several times. Polymer was obtained as a colorless viscous liquid in $56 \%$ yield, with glass transition temperature $T_{\mathrm{g}}=-95^{\circ} \mathrm{C}$, and $T_{\mathrm{d}}$ Decomposition Temperature onset $=251{ }^{\circ} \mathrm{C} .{ }^{1} \mathrm{H}$ NMR $\left(\mathrm{CDCl}_{3}, \delta \mathrm{ppm}\right),-0.12-0.12$ (br, $\left.15 \mathrm{H}, \mathrm{CH}_{3} \mathrm{Si}\right)$, 0.23-0.28 (br, 4H, $\left.\mathrm{SiCH}_{2} \mathrm{CH}_{2} \mathrm{Si}\right), 0.87(\mathrm{~m}, 3 \mathrm{H}$, $\mathrm{CH}_{3} \mathrm{CHSi}$ ), and 5.53-6.04 (m, 3H, $\left.\mathrm{CH}=\mathrm{CH}_{2}\right) .{ }^{13} \mathrm{C}$ $\operatorname{NMR}\left(\mathrm{CDCl}_{3}, \delta \mathrm{ppm}\right):-1.47,-0.84,-0.21,0.08$, $1.27,7.58,8.52,8.61,9.09,11.5,131.3,139.1$. GPC (polystyrene standards): $M_{\mathrm{w}}=6148, M_{\mathrm{w}} / M_{\mathrm{n}}=1.81$. IR $\left(\mathrm{KBr}, v, \mathrm{~cm}^{-1}\right): 1595\left(\mathrm{Si}-\mathrm{CH}=\mathrm{CH}_{2}\right), 1256(\mathrm{Si}-$ $\left.\mathrm{CH}_{3}\right), 1048$ ( $\left.\mathrm{Si}-\mathrm{O}-\mathrm{Si}\right)$.
Synthesis of Hyperbranched Poly(siloxysilane) with 2Hydroxyethylthiol Terminal Group (HBPS-OH)

HBPS-V (2.49 g, $10.1 \mathrm{mmol}$ vinyl groups per g), 2hydroxyethylthiol $(1.17 \mathrm{~g}, 15 \mathrm{mmol})$, dry toluene $(5$ $\mathrm{mL})$ and AIBN (0.082 g, $0.5 \mathrm{mmol})$ were charged into a round-bottomed flask under a stream of argon. The mixture was stirred at $100^{\circ} \mathrm{C}$ for $24 \mathrm{~h}$. The solvent and excess 2-mertaptoenthanol was removed under vacuum at $90^{\circ} \mathrm{C}$. The shallow yellow product was obtained with $84 \%$ yield. $T_{\mathrm{g}}=-62.4^{\circ} \mathrm{C}$, and TGA onset $=294{ }^{\circ} \mathrm{C} .{ }^{1} \mathrm{H}$ NMR $\left(\mathrm{CDCl}_{3}, \delta \mathrm{ppm}\right),-0.12$ 0.12 (br, $15 \mathrm{H} \mathrm{CH} \mathrm{CH}_{3} \mathrm{Si}$ ), 0.28 (br, $4 \mathrm{H} \mathrm{SiCH} \mathrm{CH}_{2} \mathrm{Si}$ ), 0.87 (m, 3H, $\left.\mathrm{CH}_{3} \mathrm{CHSi}\right), 0.91$ (t, $2.4 \mathrm{~Hz}, 2 \mathrm{H}, \mathrm{SiCH}_{2}$ ), $2.56\left(\mathrm{t}, 3.0 \mathrm{~Hz}, 2 \mathrm{H}, \mathrm{CH}_{2} \mathrm{~S}\right), 2.72\left(\mathrm{t}, 5.1 \mathrm{~Hz}, 2 \mathrm{H}, \mathrm{SCH}_{2}\right.$ ), $3.70\left(\mathrm{t}, 3.3 \mathrm{~Hz}, 2 \mathrm{H}, \mathrm{CH}_{2} \mathrm{OH}\right.$ ). ${ }^{13} \mathrm{C}$ NMR (DMSO, $\delta$ ppm): $-1.47,-0.84,-0.21,0.08,1.27,7.58,8.52$, 8.61, 9.09, 11.5, 18.6, 26.0, 33.6, 60.7. IR (KBr, $v$, $\left.\mathrm{cm}^{-1}\right): 3370(\mathrm{OH}), 1256\left(\mathrm{Si}-\mathrm{CH}_{3}\right), 1049(\mathrm{Si}-\mathrm{O}-\mathrm{Si})$.

Synthesis of Hyperbranched Poly(siloxysilane) Having Rhodamine B from HBPS-OH (HBPS-RB)

HBPS-OH $(1.0 \mathrm{~g}, 3.08 \mathrm{mmol}$ unit of hydroxyl groups), rhodamine $\mathrm{B}(1.45 \mathrm{~g}, 3.08 \mathrm{mmol}), \mathrm{DCC}$ $(0.626 \mathrm{~g}, 3.08 \mathrm{mmol})$, DMAP $(0.094 \mathrm{~g}, 0.77 \mathrm{mmol})$ and dry methylene chloride $20 \mathrm{~mL}$ were charged into a round-bottom flask under argon. The mixture was stirred at room temperature for $24 \mathrm{~h}$. Insoluble fractions were filtered off from the reaction mixture, and filtrate was concentrated and filtered again. The finally mixture was dialyzed in methanol for $7 \mathrm{~d}$ until the outside solution became colorless. $T_{\mathrm{g}}=-16.5^{\circ} \mathrm{C}$, and TGA onset $=230{ }^{\circ} \mathrm{C} .{ }^{1} \mathrm{H}$ NMR $\left(\mathrm{CD}_{3} \mathrm{OD}, \delta \mathrm{ppm}\right)$, -0.12-0.12 (br, $15 \mathrm{H}, \mathrm{CH}_{3} \mathrm{Si}$ ), 0.28 (br, $4 \mathrm{H} \mathrm{SiCH} 2^{-}$ $\mathrm{CH}_{2} \mathrm{Si}$ ), 0.87 (m, 3H, $\left.\mathrm{CH}_{3} \mathrm{CHSi}\right), 0.91$ (t, $2 \mathrm{H}, \mathrm{SiCH}_{2}$ ), 1.28 (t, $6.3 \mathrm{~Hz}, 12 \mathrm{H}, \mathrm{CH}_{3}$ ), 2.39 (t, $2 \mathrm{H}, \mathrm{SiCH}_{2} \mathrm{CH}_{2} \mathrm{~S}$ ), 2.52 (br, $2 \mathrm{H}, \mathrm{SCH}_{2} \mathrm{CH}_{2}$ ), 3.57 (br, $10 \mathrm{H}, \mathrm{CH}_{3} \mathrm{CH}_{2}$, $\mathrm{SCH}_{2} \mathrm{CH}_{2} \mathrm{OH}$ ), 4.04 (br, 2H, $\mathrm{CH}_{2} \mathrm{ORB}$ ), 6.97 (br, $3 \mathrm{H}, \mathrm{CH}$ ), 7.1 (br. $3 \mathrm{H}, \mathrm{CH}), 7.4$ (d, $6.9 \mathrm{~Hz}, 1 \mathrm{H} \mathrm{CH}$ ), $7.86(\mathrm{~m}, 2 \mathrm{H}, \mathrm{CH}), 8.3(\mathrm{br}, 1 \mathrm{H}, \mathrm{CH}) .{ }^{13} \mathrm{C} \mathrm{NMR}$ $\left(\mathrm{CD}_{3} \mathrm{OD}, \delta \mathrm{ppm}\right):-1.47,-0.84,-0.21,0.08,1.27$, $7.58,8.52,8.61,9.09,11.5,12.4,18.6,26.0,29.7$, 33.6, 45.2, 60.7, 64.9, 114.5, 115.1, 159.7, 166. IR $\left(\mathrm{KBr}, v, \mathrm{~cm}^{-1}\right): 1721(\mathrm{C}=\mathrm{O}), 1590\left(\mathrm{C}_{\mathrm{Ar}}=\mathrm{C}_{\mathrm{Ar}}\right)$, $1256\left(\mathrm{Si}-\mathrm{CH}_{3}\right), 1048(\mathrm{Si}-\mathrm{O}-\mathrm{Si})$ (Figure 3).

Preparation of Samples for Measurement of UV-Visible and Fluorescence Spectra

Typical experimental are described as follows. RB $(4.9 \mathrm{mg})$ was dissolved in methanol $(100 \mathrm{~mL})$ under ultrasonic stirring for $15 \mathrm{~min}$. This solution is the stock solution. The different concentrations of RB were prepared by diluting the stock solution.

HBPS-RB $139.7 \mathrm{mg}$ (with 34\% RB terminal group) was put into methanol $(100 \mathrm{~mL})$ under stirring for 30 min. This solution with $1.87 \mathrm{M}$ (concentration of RB 


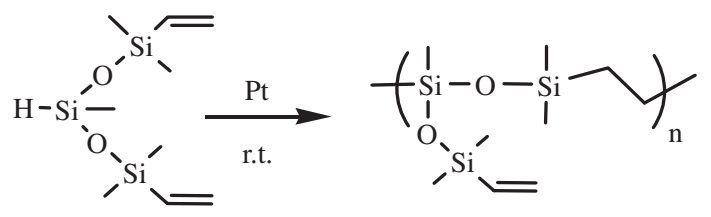

Scheme 1.

conjugated to polymer) was used as stock solution. Different concentrations of HBPS-RB were carried out by diluting stock solution.

Contents of RB unit in HBPS were calculated based on the following observation. Quantitative analysis is based on the application of the BEER-LAMBERT LAW, which is given by

$$
A=\varepsilon b c
$$

Where $\mathrm{A}$ is absorbance, $\varepsilon$ is molar absorption coefficient $\left(\mathrm{L} \mathrm{mol}^{-1} \mathrm{~cm}^{-1}\right), c$ is the concentration of compound in solution $\left(\mathrm{mol} \mathrm{L}^{-1}\right), b$ is the path length of the sample $(\mathrm{cm})$.

\section{RESULTS AND DISCUSSION}

\section{Preparation of HBPS-V}

HBPS was prepared by hydrosilation of $\mathrm{AB}_{2}$ monomer as shown in Scheme 1. However, the synthesized hyperbranched poly(siloxysiliane)s actually did not have such a highly regular structure. Intramolecular cyclization via terminal groups including $\mathrm{Si}-\mathrm{H}$ or double bonds is a very common side reaction which can lead to different cyclic species. ${ }^{36}$ In an attempt to minimize undesired cyclic species from intramolecular reaction, we use bulk reaction that can keep the concentration of reactive functionalities as high as possible. The ${ }^{1} \mathrm{H}$ NMR and ${ }^{13} \mathrm{C}$ NMR spectra show that the hydrosilation reaction yields preferentially $\beta$ addition products eventhough a nonnegligible proportion of $\alpha$ addition product are also observed. For example, an analysis of HBPS-V by ${ }^{1} \mathrm{H}$ NMR spectroscopy reveals a signal at $0.87 \mathrm{ppm}$ that can be assigned to the methyl group resulting from $\alpha$ addition, whereas $\beta$ addition gives signals at $0.1-0.5 \mathrm{ppm}$. Relative integration of $\alpha$ and $\beta$ signals indicates that $\alpha$ addition is present in $\sim 35 \%$ of the linkages. The ${ }^{13} \mathrm{C}$ NMR spectra of the polymer also indicate that both types of addition are taking place. The carbon signals of methyl and methine units resulting from $\alpha$ addition were appeared at 7.5 and $11.4 \mathrm{ppm}$, respectively. Signals of methylene units due to $\beta$ addition were appeared between 8.5 and $9.1 \mathrm{ppm}$. This polymer had good solubility in many solvents, such as ether, hexane, and THF. GPC measurements indicated that the molecular weight for this polymer was about 6148 with polydipersity of 1.8 .

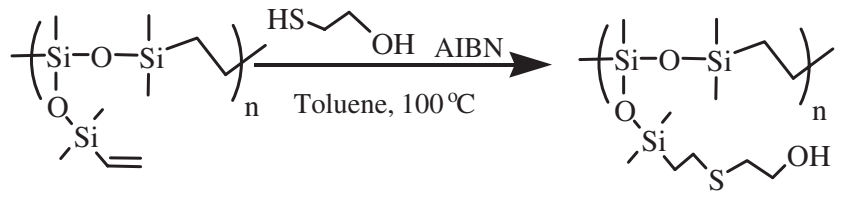

Scheme 2.

\section{Preparation of $\mathrm{HBPS}-\mathrm{OH}$}

The HBPS-OH was prepared by the radical reaction of HBPS-vinyl with 2-mercaptoethanol, as shown in Scheme 2. The addition of the thiol to HBPS-V was carried out using AIBN as a radical initiator. In the ${ }^{1} \mathrm{H}$ NMR spectrum of HBPS-OH, the vinyl peaks at 5.5-6.0 ppm were disappeared, and new peaks for methylenes appeared at 0.91 and $2.56 \mathrm{ppm}$, respectively. Furthermore, ${ }^{13} \mathrm{C}$ NMR spectrum shows that the peaks at 139.1 and $131.2 \mathrm{ppm}$, corresponding to the vinyl groups, shifted to 26.2 and $18.8 \mathrm{ppm}$ corresponding to methylene adjacent to thiol atom and silicon atom, respectively. These results indicate that conversion of end-capping reaction for vinyl groups proceeded with $100 \%$ efficiency. The yield was $84 \%$. The HBPS-OH showed good solubility in many organic solvents, such as $\mathrm{CHCl}_{3}$, ether, THF, DMF and methanol. They did not dissolve in hexane and toluene because they have polar $\mathrm{OH}$ terminal group. Weight average molecular weight $\left(M_{\mathrm{w}}\right)$ of the HBPS-OH determined by GPC with THF eluent was 8600 with a polydispersity of 1.85 .

\section{Preparation of HBPS-RB}

The synthesis of HBPS-RB was shown in Scheme 3. Because poly(siloxysilane) is unstable in strong acidic condition and RB is unstable in basic condition due to forming $\mathrm{RB}$ base, combination of DCC and DMAP is suitable for the reaction in neutral condition. ${ }^{1} \mathrm{H}$ NMR (Figure 1) and ${ }^{13} \mathrm{C}$ NMR spectra (Figure 2) depicted the changes of peak position of protons and carbons before and after reaction.

Methylene groups shifted the peaks of proton from ca. 2.52 and $3.54 \mathrm{ppm}$ to $c a .2 .39$ and $4.04 \mathrm{ppm}$, respectively. From ${ }^{1} \mathrm{H}$ NMR spectrum, relative integration of methylene adjacent to ester group and methylene adjacent to an unreacted hydroxyl group signals, we can calculate that $c a$. $34 \%$ of terminal groups have been conjugated to RB. The remained $66 \%$ of metylene signals overlap with peaks 6 and 14 after reaction. The ${ }^{13} \mathrm{C}$ NMR spectrum showed that methylene groups shifted the peaks of carbon from $c a .33$ and $60 \mathrm{ppm}$ to $c a .30$ and $65 \mathrm{ppm}$ (after reaction), respectively. The carbonyl carbon peak $(\mathrm{C}=\mathrm{O})$ of $\mathrm{RB}$ shifted from $168.2 \mathrm{ppm}$ to $166.5 \mathrm{ppm}$. IR spectrum showed carbonyl $(\mathrm{C}=\mathrm{O})$ of ester vibration energy peak ap- 


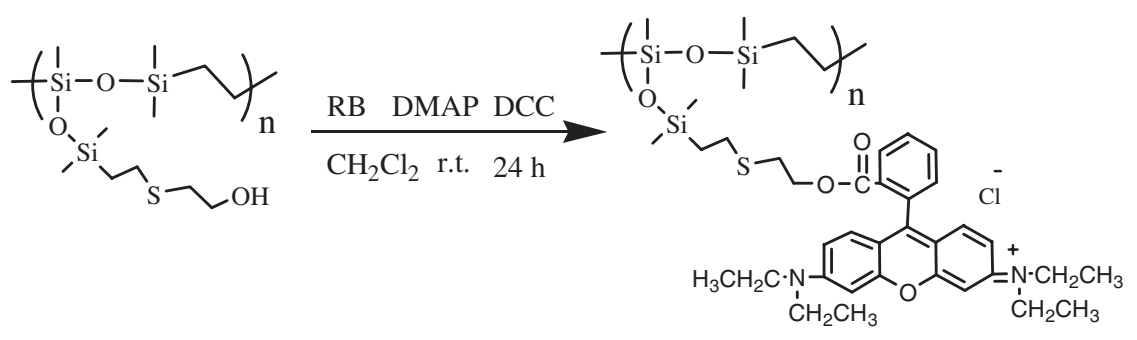

Scheme 3.

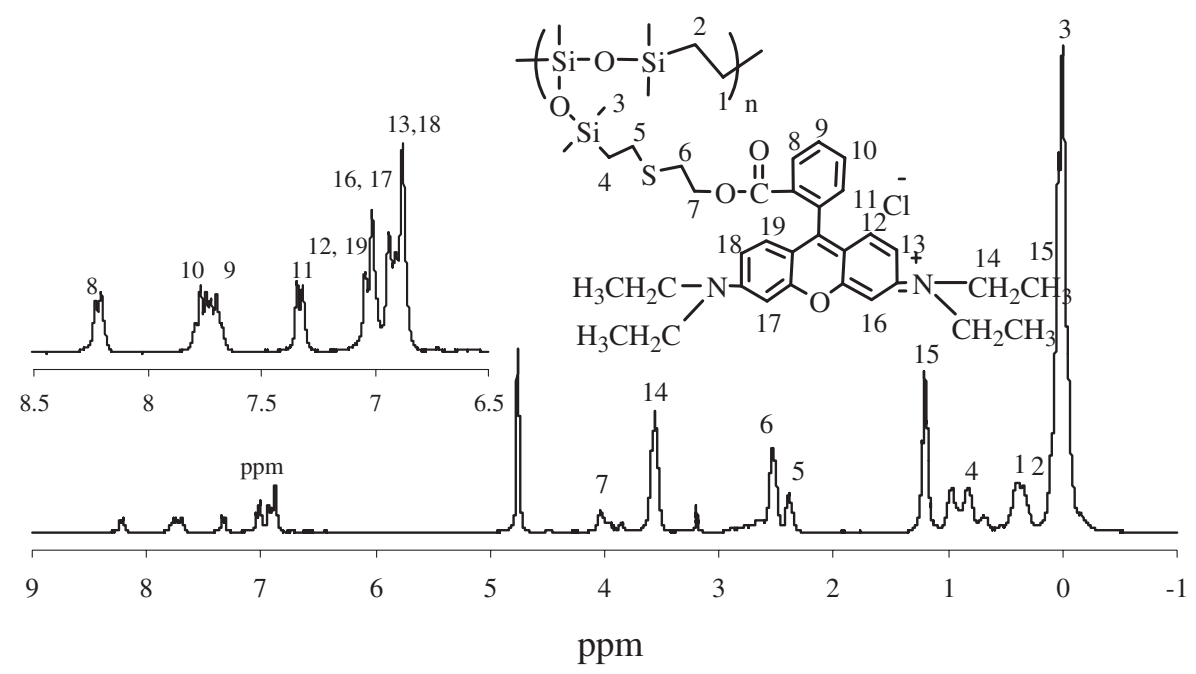

Figure 1. ${ }^{1} \mathrm{H}$ NMR spectrum of HBPS with RB terminal group.

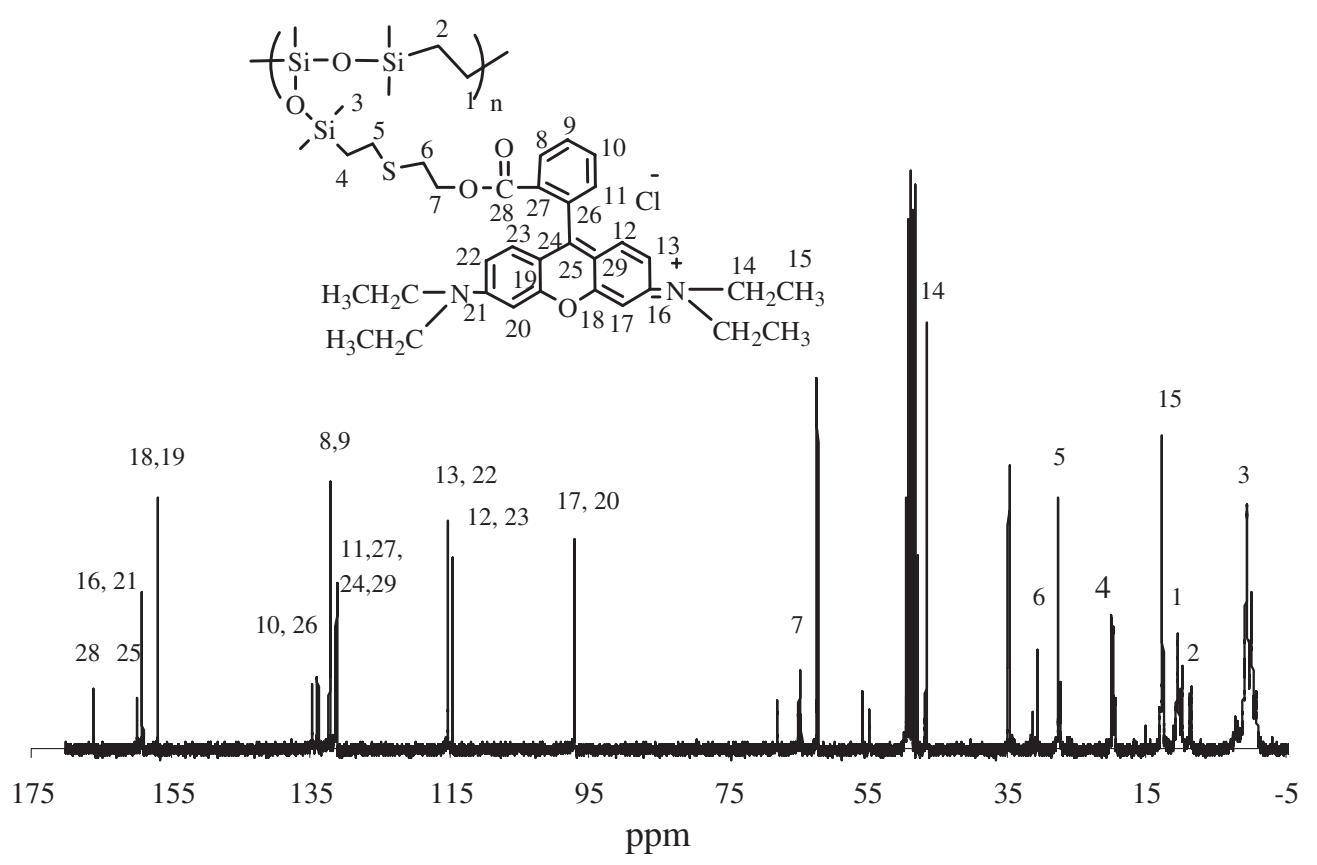

Figure 2. ${ }^{13} \mathrm{C}$ NMR spectrum of HBPS with RB terminal group.

peared at $1721 \mathrm{~cm}^{-1}$. These data indicated that $\mathrm{RB}$ was successfully connected to HBPS-OH. The average molecular weight of HBPS-RB was 12,400(calcu- lated according to amount of conjugation of RB). The solubility of HBPS-RB has also changed resulting in dissolving in methanol and partly in THF. 


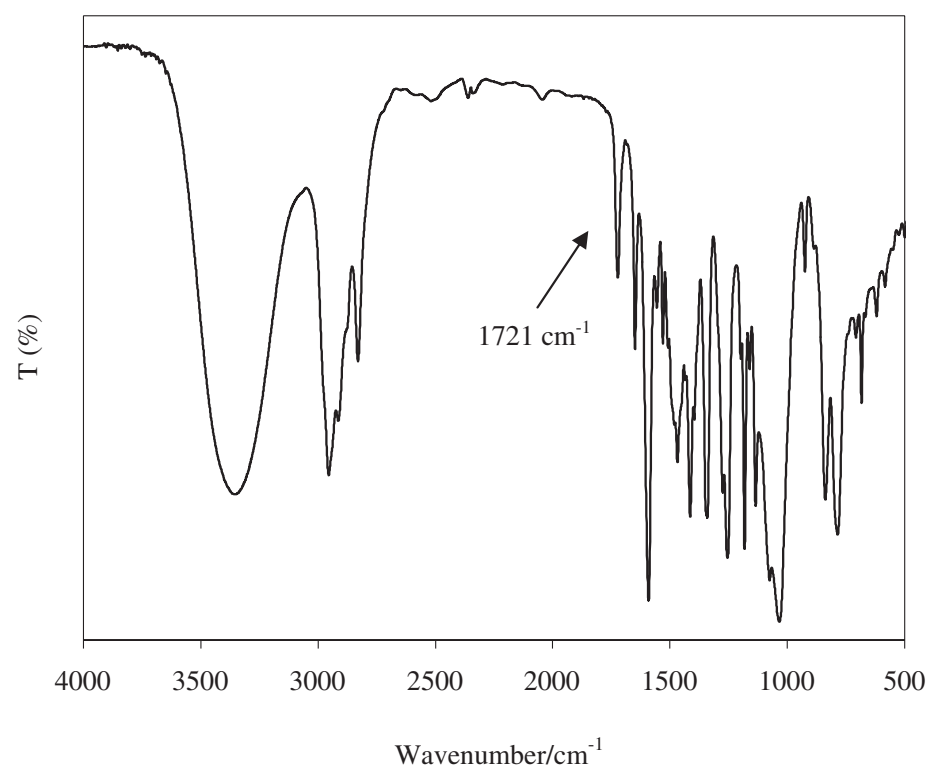

Figure 3. Infrared spectrum of HBPS with RB terminal group.

\section{Thermal Behavior of Polymers}

It has been shown that the $T_{\mathrm{g}}$ of hyperbranched polymers is greatly influenced by the characteristics of the terminal functionality. Thus, HBPS-V, HBPS$\mathrm{OH}$, and HBPS-RB have $T_{\mathrm{g}} s-95,-62.4$ and $-16.5^{\circ} \mathrm{C}$, respectively.

\section{UV-Visible Absorption and Fluorescence Spectra}

Contents of RB unit in HBPS were calculated using BEER-LAMBERT LAW based on the following equation:

$$
C_{\mathrm{o}}=\frac{A_{\mathrm{o}}}{A_{\mathrm{s}}} \times C_{\mathrm{s}}
$$

$A_{\mathrm{o}}$ is observation absorbance of RB in polymer, $A_{\mathrm{S}}$ is standard absorbance of RB in methanol. $C_{\mathrm{s}}$ is the concentration of RB, $C_{\mathrm{o}}$ is the concentration of $\mathrm{RB}$ in polymer. From this equation, we can obtain concentration of RB in polymer (Figure 4a). Finally, we can calculated that $32.4 \% \mathrm{RB}$ had been conjugated to polymer. UV-visible absorption spectra of HBPS-RB were shown in Figure 4b. Fluorescence intensity increased with increasing concentration of HBPS-RB (Figure 5). At high concentration $(1.87 \mathrm{M}$ of $\mathrm{RB}$ in methanol) of HBPS-RB, fluorescence quenching did not occur (Figure 6). Fluorescence quenching occurs when concentration of RB without polymer in methanol solution is higher than $8.64 \times 10^{-4} \mathrm{M}$. These results indicate that RB molecules were separated by branching of polymer result in fluorescence quench did not occur. Hyperbranched poly(siloxysilane) is good matrix for RB laser dye because they have thermal stability and depressed aggregation of RB. In order to demonstrate the effect of using hyperbranched polymer, fluorescence properties of mixture a)
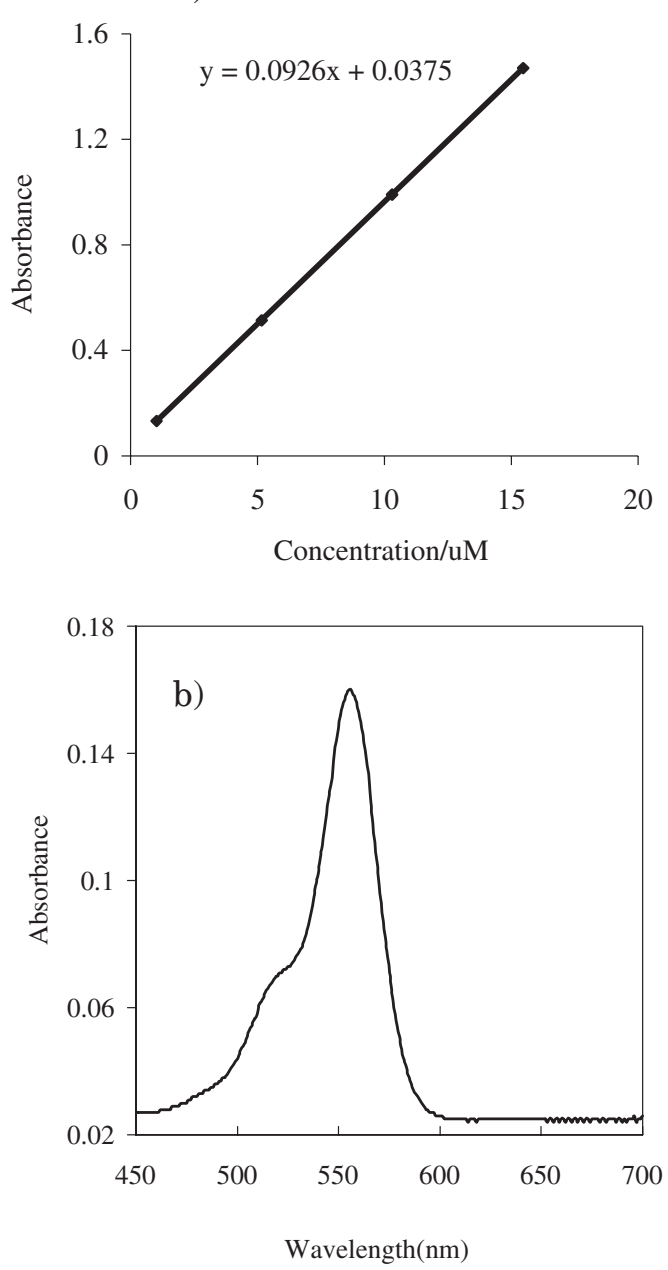

Figure 4. a) Standard curve of absorption spectra of RB in methanol (absorbance of RB was measured at $545 \mathrm{~nm}$ ). b) UVVisible absorption spectra of HBPS with RB terminal group in methanol solution. $\mathrm{C}=7.48 \times 10^{-6} \mathrm{M}$. The maximum peak is $556 \mathrm{~nm}$. 

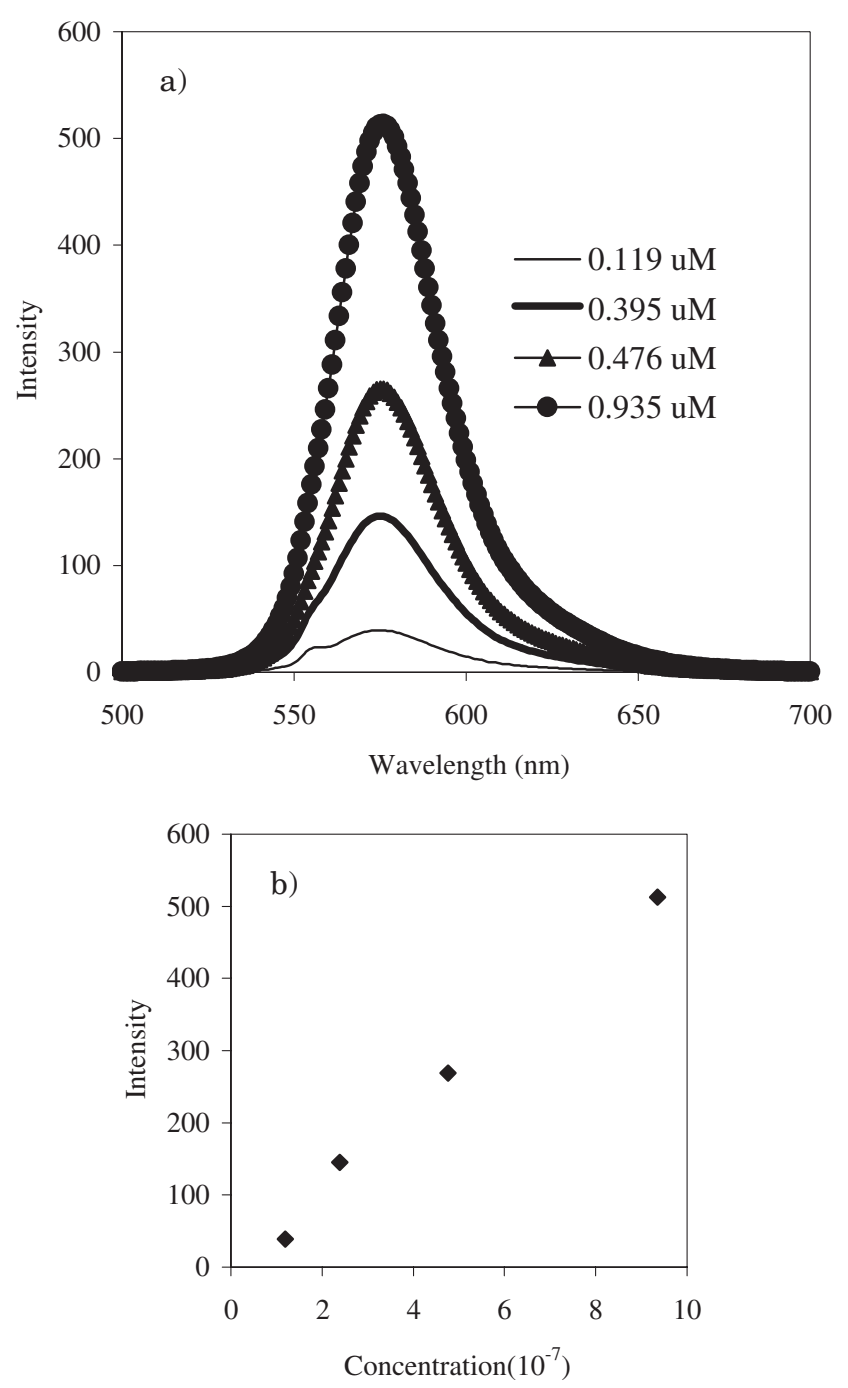

Figure 5. a) Fluorescence spectra of HBPS with RB terminal group in methanol $\left(\lambda_{\mathrm{ex}}=554 \mathrm{~nm}\right)$. a: $1.19 \times 10^{-7} \mathrm{M}$, b: $3.95 \times$ $10^{-7} \mathrm{M}$, c: $4.76 \times 10^{-7} \mathrm{M}$, d: $9.35 \times 10^{-7} \mathrm{M}$. b) Fluorescence intensity of HBPS with RB terminal group in different concentration.

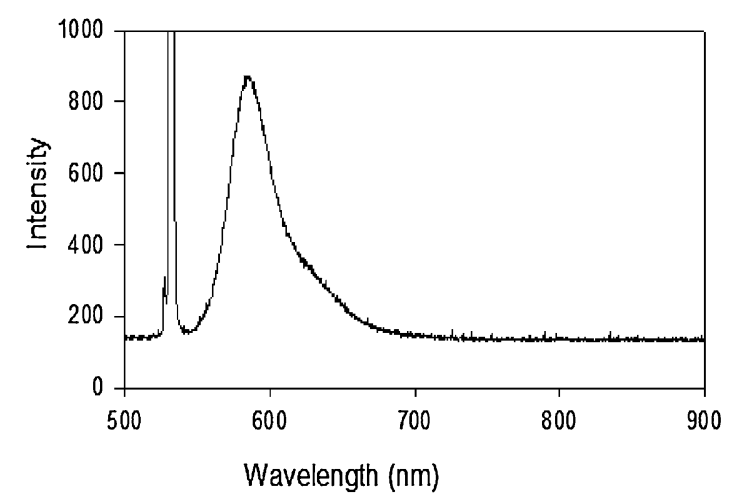

Figure 6. Fluorescence spectra of HBPS with RB terminal group in methanol $\left(\lambda_{\mathrm{ex}}=532 \mathrm{~nm}\right), \mathrm{C}=1.87 \mathrm{M}$.

of HBPS-OH and RB was discussed. At the low concentration of RB mixed with HBPS-OH, there is little difference compared with that of HBPS-RB.
The concentration of dye concentration is important point for the stable laser source. HBPS-RB, which has high content of $R B$, is very excellent point for the stable laser source.

\section{CONCLUSION}

Rhodamine B was introduced at the terminal position of hyperbranched poly(siloxysilane). It was found that about $34 \%$ of terminal positions of hyperbranched poly(siloxysilane) were occupied with RB judged from UV-visible and ${ }^{1} \mathrm{H}$ NMR spectra. The UV-Visible and fluorescence spectra indicate that hyperbranched poly(siloxysilane) matrix disturb dye aggregation. This polymer has potential application in laser device.

Acknowledgment. Authors appreciate Dr. Shiyoshi Yokoyama in National Institute of Information and Communication Technology for spectra measurement.

\section{REFERENCES}

1. "Dye Laser," 2nd ed., F. P. Schaefer, Ed., Springer, Berlin, 1977.

2. K. H. Drexhage, "Dye Laser," F. P. Schafer, Ed., Springer, Berlin, 1973, p 144.

3. R. W. Chambers, T. Kajiwara, and D. R. Kearns, J. Phys. Chem., 78, 380 (1994).

4. J. G. Calvert and J. N. Pitts, "Photochemistry" Wiley, New York, 1996, p 799.

5. I. L. Valdes-Aguilera and D. C. Neckers, Acc. Chem. Res., 22, 171 (1989).

6. C. Rottman, G. Graden, Y. D. Hazan, S. Melchior, and D. Avnir, J. Am. Chem. Soc., 121, 8533 (1999).

7. T. S. Lee and C. Yang, Polym. Bull., 42, 655 (1999).

8. B. Müller, React. Funct. Polym., 39, 165 (1999).

9. M. LaI, S. Paakatchi, G. S. He, and P. N. Prasad, Chem. Mater., 11, 3012 (1999).

10. J. E. Selwyn and J. I. Steinfield, J. Phys. Chem., 76, 762 (1972).

11. A. Seeboth, J. Kriwanok, and R. J. Vetter, Mater. Chem. Commun., 9, 2777 (1999).

12. M. J. T. Esttevez and F. L. Arbeola, J. Colloid Interface Sci., 171, 439 (1995).

13. A. Adronov, J. M. J. Fréchet, and G. R. Fleming, J. Am. Chem. Soc., 122, 1175 (2000).

14. S. L. Gilat, A. Adronov, and J. M. J. Fréchet, J. Org. Chem., 64, 7474 (1999).

15. S. Yakoyama, T. Nakahama, A. Otomo, and S. Mashiko, Thin Solid Films, 393, 124 (2001).

16. C. K. Kim and K. G. Kwark, J. Polym. Sci., Part A: Polym. Chem., 40, 976 (2002).

17. Y. Kim and O. W. Webster, Polym. Prepr. (Am. Chem. Soc., Div. Polym. Chem.), 29(2), 310 (1988).

18. M. Jikei and M. Kakimoto, Prog. Polym. Sci., 26, 1233 (2001). 
19. K. Inoue, Prog. Polym. Sci., 25, 453 (2000).

20. Y. Kim and O. Webster, Macromolecules, 25, 5561 (1992).

21. C. Gao and D. Yan, Prog. Polym. Sci., 29, 183 (2004).

22. K. L. Wooley, C, J. Hawker, R. Lee, and J. M. J. Fréchet, Polym. J., 26, 187 (1994).

23. M. Borkovec and G. Koper, Colloid Polym. Sci., 109, 142 (1998).

24. H. Mori, D. Seng, H. Lechner, and M. Zhang, Macromolecules, 35, 9270 (2002).

25. Y. Kim, J. Polym. Sci., Part A: Polym. Chem., 36, 1685 (1998).

26. R. Smits and G. Koper, Phys. Chem., 194, 1953 (1993).

27. C. Hong and C. Pan, Polymer, 42, 9385 (2001).

28. J. M. Zeigler, "In Silicon-Based Polymer Science: A Comprehensive Resource" F. W. G. Fearon, Ed., Washington, D. C., 1990.

29. C. Burger, W. R. Hertler, P. F. Kochs, H. Kreuzer, H. R. Kircheldorf, and R. Mülhaupt, "In silicon in Polymer synthesis," H. R. Kircheldorf, Ed., SpringerVerlag, Washington, D. C., 1990.
30. S. J. Clarson, "In Siloxane Polymers," J. A. Senlyen, Ed., N. J. Englewood Cliff, 1993.

31. H. R. Kricheldorf, "Sillicon in Polymer Synthesis," World Publishing Company, Beijing, 1996, p 404.

32. J. M. J. Fréchet, C. J. Hawker, and J. W. Leon, J. Macromol. Sci., Pure Appl. Chem., 33, 1399 (1996).

33. L. J. Mathias and T. W. Carothers, J. Chem. Soc., 113, 4043 (1991).

34. A. M. Mauzafarov, M. Golly, and M. Möller, Macromolecules, 28, 8444 (1995).

35. S. J. Rubinsztajn, J. Inorg. Organomet. Polym., 4, 61 (1994).

36. J. F. Miravet and J. M. J. Fréchet, Macromolecules, 31, 3461 (1998).

37. C. Gong, J. F. Miravet, and J. M. J. Fréchet, J. Polym. Sci., Part A: Polym. Chem., 38, 2970 (1999).

38. C. Gong, J. F. Miravet, and J. M. J. Fréchet, J. Polym. Sci., Part A: Polym. Chem., 37, 3193 (2000).

39. J. Z. Yao and D. Y. Son, J. Polym. Sci., Part A: Polym. Chem., 37, 3778 (1999). 